\title{
Geochemical significance of a garnet lherzolite from the Dahongshan kimberlite, Yangtze Craton, southern China
}

\author{
Hong-Fu Zhang,,${ }^{1,2} *$ Min Sun, ${ }^{2}$ Feng-Xiang Lu ${ }^{3}$ Xin-Hua Zhou, ${ }^{1}$ MeI-Fu Zhou, ${ }^{2}$ \\ YONG-SHUN LIU ${ }^{4}$ and GUO-HUI ZHANG ${ }^{1}$ \\ ${ }^{1}$ Laboratory of Lithosphere Tectonic Evolution, Institute of Geology and Geophysics, \\ Chinese Academy of Sciences, P.O. Box 9825, Beijing 100029, P.R. China \\ ${ }^{2}$ Department of Earth Sciences, The University of Hong Kong, Pokfulam Road, Hong Kong \\ ${ }^{3}$ Faculty of Earth Sciences, China University of Geosciences, Wuhan 430074, P.R. China \\ ${ }^{4}$ Department of Geography, Capital Normal University, Beijing 100037, P.R. China
}

(Received December 11, 2000; Accepted July 18, 2001)

\begin{abstract}
The Dahongshan kimberlite field in Hubei Province, China, is situated in the northern margin of the Proterozoic Yangtze Craton. The kimberlites erupted in the Paleozoic ( $c a .326 \mathrm{Ma}$ ), some of which are associated with barren lamproites. An unusually fresh garnet lherzolite collected from this kimberlite field provides an opportunity to directly study the nature of the Paleozoic lithospheric mantle beneath the Yangtze Craton. The lherzolite is moderately depleted in major element compositions $\left(2.66 \mathrm{wt} \% \mathrm{Al}_{2} \mathrm{O}_{3}\right.$, $2.82 \mathrm{wt} \% \mathrm{CaO}$, and $90.9 \mathrm{Mg} \#$ ), with a forsterite content in olivine around $90.5 \%$. The rare earth element characteristics of the whole rock $\left[(\mathrm{La} / \mathrm{Sm})_{\mathrm{N}}=13\right.$ and $\left.(\mathrm{Eu} / \mathrm{Yb})_{\mathrm{N}}=0.48\right]$ and of the constituent minerals such as clinopyroxene $\left[(\mathrm{La} / \mathrm{Yb})_{\mathrm{N}}=61\right]$ reveal that at least two processes were recorded in the lherzolite: depletion followed by enrichment. Depletion process was derived from low degree of partial melting, as demonstrated by relatively high $\mathrm{NiO}$ contents $(0.50 \%)$ in olivines and PPGE-enriched mantle-normalized PGE pattern of the whole rock. The enrichments in LREE and LILE are attributed to melt infiltration that must be an event prior to the kimberlite eruption as constrained by trace element and $\mathrm{Sr}-\mathrm{Nd}$ isotopic data. $\mathrm{The} \mathrm{Rb}-\mathrm{Sr}$ and $\mathrm{Sm}-\mathrm{Nd}$ data constrained an age of about $510 \mathrm{Ma}$, which is much older than the age of kimberlite eruption, but consistent with the eruption time of diamond-bearing lamproites on the centre of the Craton.

The stable Gt-Opx-Cpx mineral assemblage gives a T-P estimation of $1042^{\circ} \mathrm{C}$ and $34 \mathrm{kbar}$, corresponding to $110 \mathrm{~km}$ depth, well within the graphite stability field. The geotherm inferred from this lherzolite was much higher than the typical cratonic geotherm $\left(40 \mathrm{~mW} / \mathrm{m}^{2}\right)$, but still lower than the oceanic geotherm. Thus, our study and previous data demonstrate that the lithospheric mantle beneath the Yangtze craton was less depleted and was hotter in Paleozoic than the lithospheric mantle beneath typical old Cratons, i.e., the Kaapvaal, the Siberia, and the North China.
\end{abstract}

\section{INTRODUCTION}

Kimberlites occur as explosive diatremes on the old continental cratons, and the ultramafic xenoliths entrained in kimberlites usually represent samples from the upper mantle. Therefore, these xenoliths can provide important information on evolution of the continental lithospheric mantle, as previously reported for the Kaapvaal Craton, the Siberian Craton, the Wyoming Craton, the Kimberley Craton, and the Canadian Shield (Dawson, 1980; Nixon, 1987; Menzies and Hawkesworth, 1987; Griffin et al., 1984; Hoal et al., 1994; Carlson and Irving, 1994; Pearson et al., 1994, 1995). In China, a few Ordovician kimberlite pipes within the North China Craton (NCC) contain mantle xenoliths. These xenoliths are intensively altered and only a few constituent minerals are fresh enough for chemical analysis (Wang et al., 1998; Zhang et al., 2000a). In spite 
of this difficulty, garnets, chromites, and minor pyroxenes from the kimberlites and from their ultramafic xenoliths have provided valuable data on the Paleozoic geotherm and lithospheric structure of the NCC (Griffin et al., 1992; Zhou et al., 1994; Wang et al., 1998; Zhang et al., 2000a). Combined with data from the ultramafic xenoliths carried by the Cenozoic alkaline basalts, these studies manifest a lithosphere-thinning history for the NCC (Menzies et al., 1993). On the other hand, Yangtze Craton, another important craton in China, collided with the NCC in Triassic, which resulted in ultrahigh-pressure metamorphism along Dabie Mountains (Xu et al., 1992). Whether the lithospheric thinning also affected the Yangtze Craton is currently unknown, since there are virtually no data for mantle rocks from this craton. The only available mantle xenolith, a fresh garnet lherzolite, was collected from the Dahongshan kimberlite field in Hubei Province, China, which is located in the northern margin of the Yangtze Craton. This sample offers a rare opportunity to obtain the first, direct information about the lithospheric mantle beneath the Yangtze Craton. This paper presents a set of high precision geochemical and isotopic data and aims to provide some crucial insights into the mantle processes recorded in the xenolith, and further to discuss the nature and evolutionary history of the lithospheric mantle beneath the northern part of the Yangtze Craton.

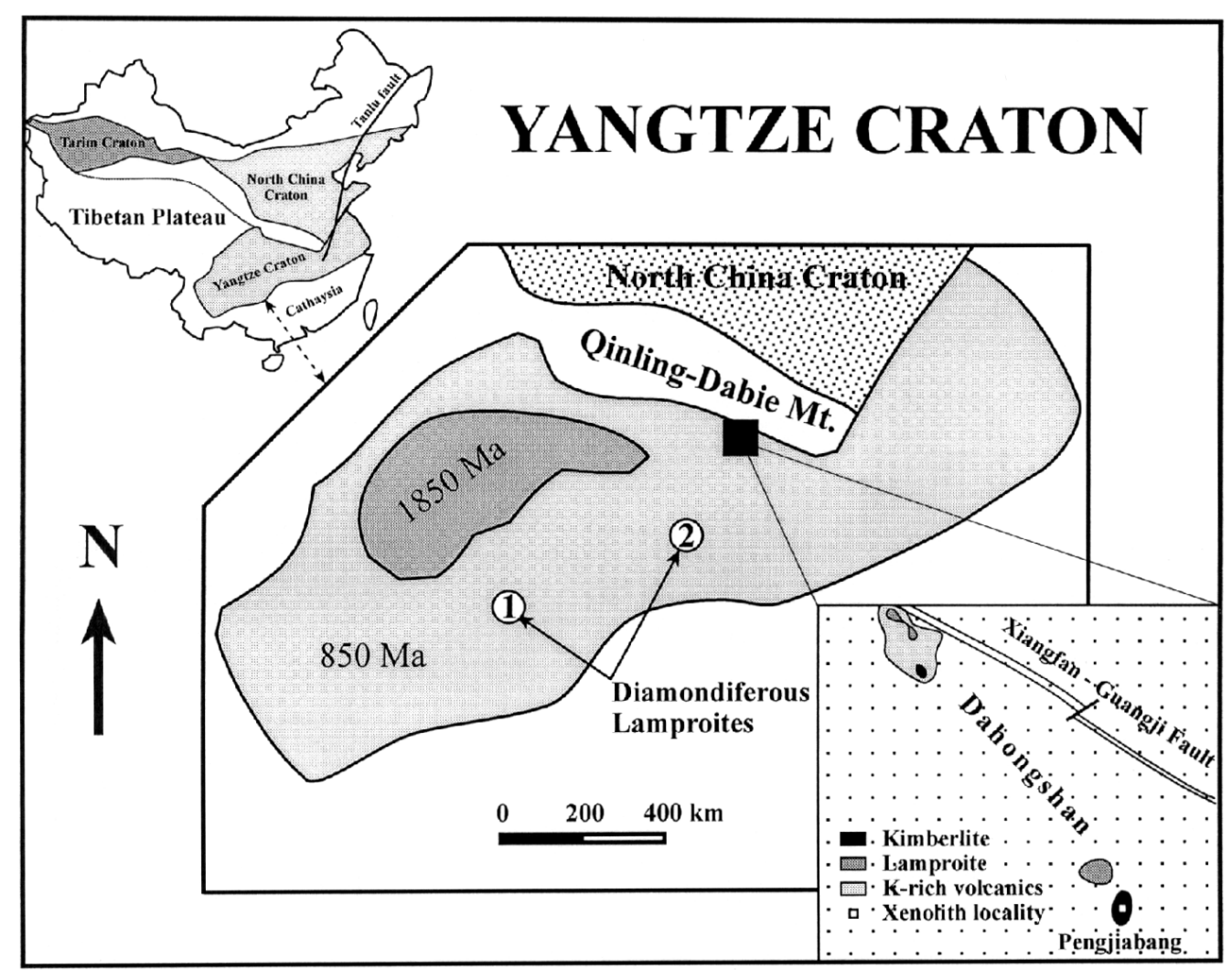

Fig. 1. Simplified tectonic map showing the location of the Yangtze Craton and the distribution of diamondiferous lamproites and diamond-free kimberlites/lamproites (modified from Ye et al. (1991) and Zhang et al. (1994)). Primary diamondiferous lamproite fields in Zhengyuan, Guizhou Province and in Ningxiang, Hunan Province are labeled as (1) and (2), respectively. The Dahongshan kimberlite/lamproite field is shown in detail and the locality of the garnet lherzolite xenolith is indicated. 


\section{Geological Settings AND Host Kimberlite}

The Yangtze Craton is one of the three major cratons in China (Fig. 1). Its basement formed in the Neoproterozoic (1.85 to $0.85 \mathrm{Ga}$ ) and is covered by the Phanerozoic sedimentary rocks (Zhang et al., 1994). Three kimberlite and/or lamproite fields are known in this craton, i.e., the Dahongshan barren kimberlites in Hubei Province, the Ningxiang diamond-bearing lamproites in Hunan Province, and the Zhengyuan diamondbearing lamproites in Guizhou Province from northeast to southwest of the Yangtze Craton (Fig. 1). The Dahongshan kimberlite field comprises about 100 small kimberlite- and lamproite-pipes or dikes, along a $70 \times 30 \mathrm{~km} \mathrm{~K}$-rich ultramafic rock belt extending northwestward along the Xiangfan-Guangji deep fault (Ye et al., 1991; Fig. 1). These kimberlites/lamproites intruded the Sinian-Ordovician carbonates (dolomitite) and shales (Liu and Zhao, 1991). Ten irregular kimberlite pipes or dikes outcrop near the Pengjiabang village, with the largest one covering only $0.05 \mathrm{~km}^{2}$. These rocks occur as breccias made of porphyritic phlogopite kimberlite-fragments, mineral crystals, and aphanitic matrix (less than 20\%). Detailed petrographic studies of the Dahongshan kimberlite field have been reported by Ye et al. (1991) and Liu and Zhao (1991). Two kimberlites from the Pengjiabang area gave very similar K-Ar whole-rock ages (326 and $327 \mathrm{Ma}$, respectively) and one lamproite from the same area gave $352 \pm 7 \mathrm{Ma} \mathrm{Rb-Sr}$ mineral isochron age (phlogopite-diopside-sanidine-apatite), respectively (Liu et al., 1993).

\section{Petrography}

Xenoliths are rare in the Dahongshan kimberlite field. A garnet lherzolite xenolith was collected from a kimberlite pipe near the Pengjiabang village (Fig. 1). It is relatively large in size (15 cm in diameter) with dark green color and rounded shape. The lherzolite is also remarkably fresh, although olivine and some orthopyroxene minerals are completely altered to brown fibrous or radial microcrystalline aggregates of serpentines and/or chlorites in the rim (Fig. 2(a)). Garnet and clinopyroxene in the rim are almost as fresh as those in the core, and all the minerals in the core of the xenolith are very fresh with only slight alteration along grain boundaries or crystal cracks of olivine. The rock is mainly composed of Ol (60\%), Opx (15\%), Cpx (15\%), and Gt (10\%), without spinel. Accordingly, it is named as garnet lherzolite. This rock has granuloblastic texture (Figs. 2(b) and (c)), with some features of deformation and recrystallization, such as kink bands in olivine and orthopyroxene and "triple junction" between olivine and pyroxene minerals.

Most of the constituent minerals, especially olivine and orthopyroxene, are granuloblastic grains dominantly in the range of $0.1 \sim 3 \mathrm{~mm}$, contrasting with the interstitial fine-grained crystals (Ol and Cpx, <0.1 mm). Granuloblastic olivines often possess small fractures filled with serpentine and magnetite. Granuloblastic orthopyroxene grains are colourless, appear as rather large crystals $(1 \sim 4 \mathrm{~mm})$ and show well-developed cleavages. A few orthopyroxene grains enclose olivine and clinopyroxene crystals to show poikilitic texture. Clinopyroxenes are light emerald diopside, small in grain size, and are scattered homogeneously in the rock. In contrast, garnets are relative large (dominantly in the range of $1 \sim 5 \mathrm{~mm}$ with the maximum up to $1 \mathrm{~cm}$ ), red-purple in color, and generally occur as anhedral crystals. Some garnets have kelyphitic rims composed of tiny pyroxene and spinel grains that are believed to be the products of garnet decomposition at relatively low pressure. The preliminary studies demonstrated that this xenolith represents the residue after low degree partial melting of the upper mantle (Liu and Zhao, 1991).

\section{SAmple Preparation ANd Analytical Methods}

The xenolith was cut into several thin slices, one of which was used to make a series of 6 polished thin-sections for electron microprobe (EMP) 

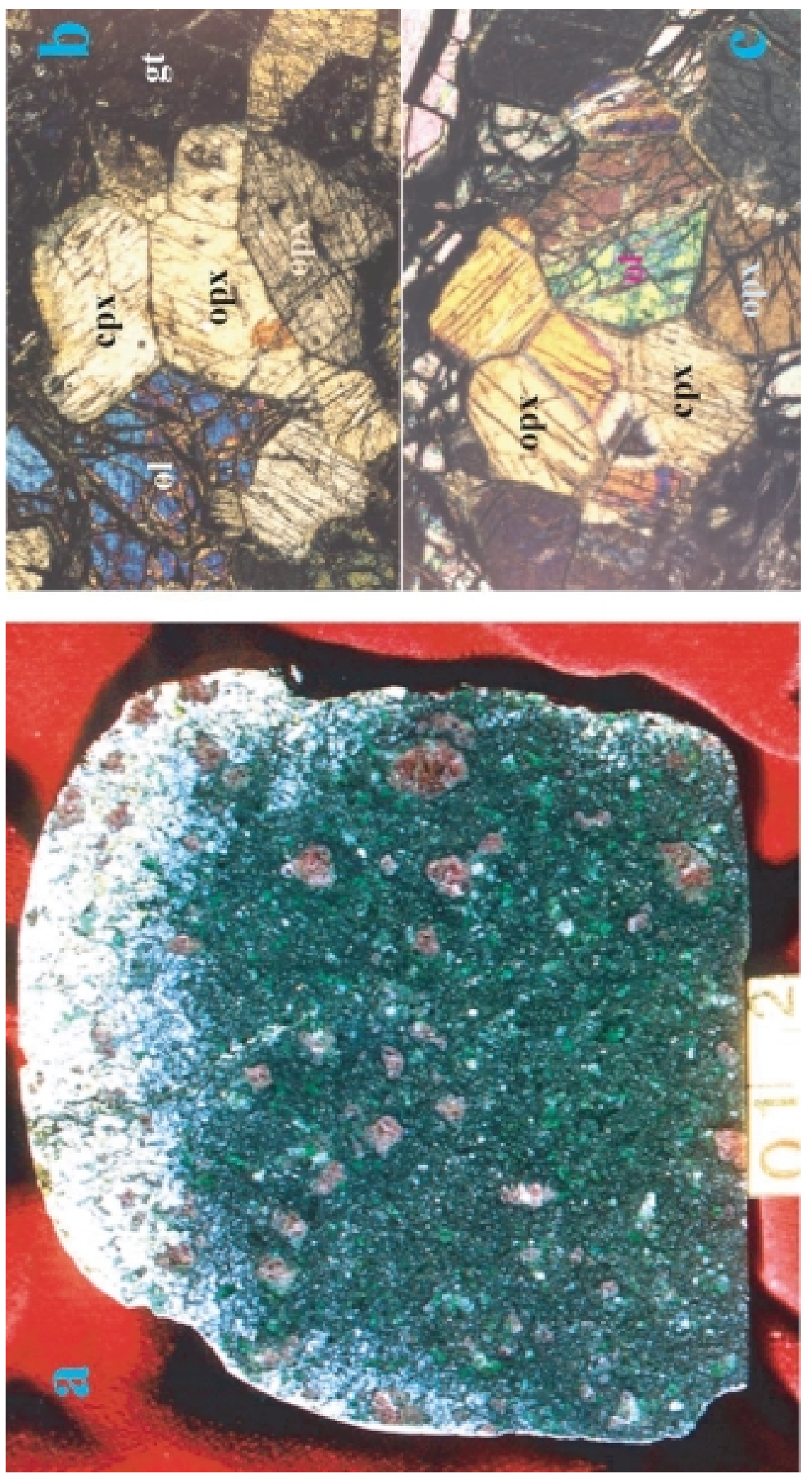

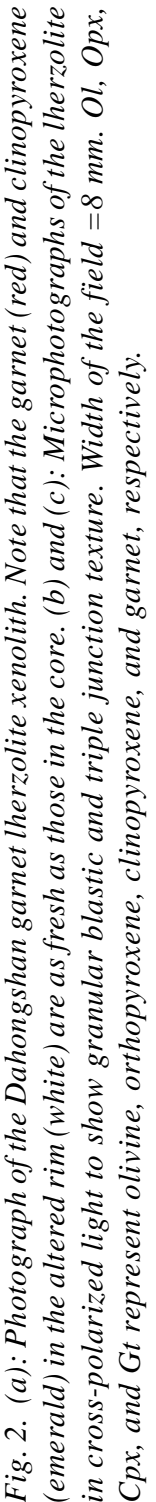


Table 1. Major element compositions (wt\%) of minerals from the Dahongshan garnet lherzolite

\begin{tabular}{|c|c|c|c|c|c|c|c|c|c|c|c|}
\hline & \multicolumn{4}{|c|}{$\mathrm{OL}$} & \multicolumn{7}{|c|}{ GT } \\
\hline & 2 & 3 & 4 & 5 & 1 & 2 & 3 & 4 & 5 & $6-C$ & $6-R$ \\
\hline $\mathrm{SiO}_{2}$ & 41.2 & 41.4 & 41.3 & 40.6 & 42.3 & 42.5 & 42.6 & 42.3 & 42.3 & 42.7 & 42.6 \\
\hline $\mathrm{TiO}_{2}$ & 0.02 & 0.00 & 0.02 & 0.00 & 0.10 & 0.10 & 0.08 & 0.08 & 0.11 & 0.19 & 0.19 \\
\hline $\mathrm{Al}_{2} \mathrm{O}_{3}$ & 0.00 & 0.00 & 0.00 & 0.00 & 21.9 & 21.8 & 22.0 & 22.1 & 21.7 & 21.9 & 21.8 \\
\hline $\mathrm{Cr}_{2} \mathrm{O}_{3}$ & 0.02 & 0.02 & 0.03 & 0.05 & 2.37 & 2.26 & 2.57 & 2.52 & 2.61 & 2.42 & 2.21 \\
\hline $\mathrm{MgO}$ & 49.0 & 49.0 & 48.8 & 49.4 & 19.7 & 19.7 & 19.7 & 20.0 & 19.6 & 19.5 & 19.8 \\
\hline $\mathrm{CaO}$ & 0.06 & 0.06 & 0.00 & 0.04 & 5.77 & 5.71 & 5.42 & 5.51 & 5.69 & 5.62 & 5.44 \\
\hline $\mathrm{MnO}$ & 0.07 & 0.08 & 0.12 & 0.09 & 0.33 & 0.32 & 0.35 & 0.30 & 0.42 & 0.32 & 0.40 \\
\hline $\mathrm{FeO}$ & 9.17 & 9.18 & 9.15 & 9.35 & 7.33 & 7.17 & 7.25 & 7.39 & 7.17 & 7.39 & 7.52 \\
\hline $\mathrm{NiO}$ & 0.45 & 0.49 & 0.52 & 0.50 & 0.00 & 0.04 & 0.02 & 0.04 & 0.02 & 0.02 & 0.00 \\
\hline $\mathrm{Na}_{2} \mathrm{O}$ & 0.01 & 0.00 & 0.02 & 0.00 & 0.01 & 0.02 & 0.01 & 0.00 & 0.03 & 0.01 & 0.02 \\
\hline \multirow[t]{2}{*}{$\mathrm{K}_{2} \mathrm{O}$} & 0.00 & 0.00 & 0.00 & 0.00 & 0.00 & 0.00 & 0.00 & 0.01 & 0.00 & 0.01 & 0.00 \\
\hline & 100.0 & 100.2 & 100.0 & 100.0 & 99.8 & 99.6 & 100.0 & 100.3 & 99.7 & 100.1 & 100.0 \\
\hline $\mathrm{Mg \#}$ & 90.5 & 90.5 & 90.5 & 90.4 & 82.7 & 83.0 & 82.9 & 82.8 & 83.0 & 82.5 & 82.4 \\
\hline
\end{tabular}

\begin{tabular}{|c|c|c|c|c|c|c|c|c|c|c|c|}
\hline & \multicolumn{5}{|c|}{ OPX } & \multicolumn{5}{|c|}{ CPX } & \multirow{2}{*}{$\frac{\mathrm{GT}}{*}$} \\
\hline & 1 & 2 & 3 & 4 & 5 & 1 & 2 & 3 & 4 & 5 & \\
\hline $\mathrm{SiO}_{2}$ & 57.3 & 57.5 & 57.0 & 57.5 & 57.5 & 54.0 & 54.3 & 54.3 & 54.2 & 54.3 & 43.4 \\
\hline $\mathrm{TiO}_{2}$ & 0.03 & 0.07 & 0.09 & 0.00 & 0.09 & 0.14 & 0.17 & 0.22 & 0.15 & 0.21 & 1.21 \\
\hline $\mathrm{Al}_{2} \mathrm{O}_{3}$ & 1.60 & 1.59 & 1.70 & 1.60 & 1.63 & 2.68 & 2.98 & 2.71 & 2.98 & 2.71 & 15.87 \\
\hline $\mathrm{Cr}_{2} \mathrm{O}_{3}$ & 0.37 & 0.39 & 0.37 & 0.33 & 0.30 & 1.18 & 1.22 & 1.17 & 1.16 & 1.12 & 2.51 \\
\hline $\mathrm{MgO}$ & 34.3 & 34.3 & 34.0 & 34.3 & 34.2 & 16.5 & 16.6 & 16.9 & 16.9 & 16.9 & 11.4 \\
\hline $\mathrm{CaO}$ & 0.54 & 0.58 & 0.60 & 0.50 & 0.60 & 20.9 & 20.5 & 21.0 & 20.3 & 20.3 & 20.8 \\
\hline $\mathrm{MnO}$ & 0.05 & 0.07 & 0.09 & 0.13 & 0.13 & 0.06 & 0.14 & 0.08 & 0.00 & 0.13 & 0.18 \\
\hline $\mathrm{FeO}$ & 5.96 & 5.86 & 6.00 & 6.09 & 5.74 & 2.79 & 2.67 & 2.67 & 2.60 & 2.82 & 4.11 \\
\hline $\mathrm{NiO}$ & 0.09 & 0.02 & 0.02 & 0.08 & 0.08 & 0.10 & 0.00 & 0.05 & 0.00 & 0.06 & 0.09 \\
\hline $\mathrm{Na}_{2} \mathrm{O}$ & 0.06 & 0.08 & 0.05 & 0.08 & 0.02 & 1.40 & 1.52 & 1.46 & 1.51 & 1.51 & 0.60 \\
\hline \multirow[t]{2}{*}{$\mathrm{K}_{2} \mathrm{O}$} & 0.00 & 0.02 & 0.02 & 0.01 & 0.00 & 0.01 & 0.07 & 0.05 & 0.08 & 0.02 & 0.00 \\
\hline & 100.3 & 100.5 & 99.9 & 100.6 & 100.3 & 99.8 & 100.2 & 100.6 & 99.9 & 100.1 & 100.2 \\
\hline $\mathrm{Mg \#}$ & 91.1 & 91.3 & 91.0 & 90.9 & 91.4 & 91.4 & 91.7 & 91.8 & 92.1 & 91.4 & 83.1 \\
\hline
\end{tabular}

*Fine-grained garnet in groundmass. C: Centre; R: Rim. OPX1, CPX1, and GT1 were probed at the altered rim where OL was completely serpentinized, but all other minerals in the rim are as fresh as their counterparts in the unaltered core (1 5 indicates minerals from the altered rim to the core).

analyses. The EMP data were obtained with the Cameca SX50 at the Institute of Geology and Geophysics (IGG), Chinese Academy of Sciences, and the results are presented in Table 1 . The rest rock slices were trimmed to remove the altered rims and were divided into two parts. The first part was cleaned with deionized water and then powdered with agate mill to 200 mesh for major, trace elements and $\mathrm{Sr}-\mathrm{Nd}$ isotopic analyses. The second part was crushed to $40-80$ mesh for min- eral separation. Constituent minerals (Ol, Opx, Cpx, Gt) without visible inclusions and fractures were then carefully hand-picked under a binocular microscope. The mineral separates were placed in small beakers and cleaned with acetone in ultrasonic bath for 20 minutes, rinsed with double distilled water, and then dried. Finally, the mineral separates were carefully powdered by hand with agate mortar to 200 mesh for trace elemental and isotopic analyses. 
Table 2. Major element compositions of the garnet lherzolite from the Dahongshan kimberlite, primitive mantle, and worldwide garnet lherzolite

\begin{tabular}{|c|c|c|c|c|c|c|c|c|c|c|c|c|c|c|c|}
\hline & $\mathrm{SiO}_{2}$ & $\mathrm{TiO}_{2}$ & $\mathrm{Al}_{2} \mathrm{O}_{3}$ & $\mathrm{Cr}_{2} \mathrm{O}_{3}$ & $\mathrm{Fe}_{2} \mathrm{O}_{3}$ & $\mathrm{FeO}$ & $\mathrm{MnO}$ & $\mathrm{MgO}$ & $\mathrm{NiO}$ & $\mathrm{CaO}$ & $\mathrm{Na}_{2} \mathrm{O}$ & $\mathrm{K}_{2} \mathrm{O}$ & $\mathrm{P}_{2} \mathrm{O}_{5}$ & Total & $\mathrm{Mg} \#$ \\
\hline DHS & 44.26 & 0.13 & 2.66 & 0.43 & 8.14 & & 0.12 & 40.94 & 0.33 & 2.82 & 0.12 & 0.08 & 0.05 & 100.1 & 90.9 \\
\hline PM & 44.80 & 0.21 & 4.45 & 0.38 & & 8.40 & 0.14 & 37.20 & 0.24 & 3.60 & 0.34 & 0.03 & 0.02 & 99.8 & 88.8 \\
\hline GT L-W & 45.55 & 0.09 & 1.23 & 0.35 & & 7.26 & 0.11 & 44.20 & 0.27 & 0.90 & 0.08 & 0.05 & 0.02 & 100.1 & 91.6 \\
\hline GT L-M & 44.46 & 0.18 & 4.17 & 0.45 & & 8.30 & 0.14 & 37.24 & 0.24 & 3.45 & 0.28 & 0.03 & 0.05 & 99.0 & 88.9 \\
\hline
\end{tabular}

$M g \#=100 \times M g /\left(M g+F^{2+}+F^{3+}\right)$ atomic ratio. Data for the garnet lherzolite in this study (DHS) were derived from XRF analyses, except $\mathrm{Cr}_{2} \mathrm{O}_{3}$ and $\mathrm{NiO}$ which were calculated from mineral modes and mineral compositions (see Table 1). PM and $G T L-W$ stand for primitive mantle and the average composition of garnet lherzolite from kimberlites in the world (McDonough, 1994). GT L-M is the average of 8 Cenozoic basalt-borne garnet lherzolites from the Mingxi area, Southeastern China (Liu et al., 1985; Huang et al., 1992; Qi et al., 1995).

Major oxides for the garnet lherzolite were analyzed with a Phillips PW2400 sequential Xray fluorescence (XRF) spectrometer at the University of Hong Kong (HKU). Fused glass disks were used and the analytical precision was $\leq 2 \%$. The results are given in Table 2. For trace element analyses, samples $(100 \mathrm{mg})$ were weighed and then dissolved in distilled $\mathrm{HF}-\mathrm{HNO}_{3}$ in $15 \mathrm{ml}$ Savillex Teflon screw-cap capsules at $100^{\circ} \mathrm{C}$ for 2 days, dried and then digested with $6 \mathrm{M} \mathrm{HCl}$ at $150^{\circ} \mathrm{C}$ for 4 days. Dissolved samples were diluted to $100 \mathrm{ml}$ before analyses (for Opx and $\mathrm{Ol}$, to 50 $\mathrm{ml}$ ). A blank solution was prepared and the total procedural blanks were $<50 \mathrm{ng}$ for all the trace elements reported in this paper. Three duplicates of the whole rock and two standards (BEN, BHVO-1) were prepared using the same procedure to monitor the analytical reproducibility. Trace elements of these sample solutions were analyzed with a VG Elemental Plasma-Quad 3 at HKU. The discrepancy between the triplicates is less than $10 \%$ for all the elements given in Table 3. Analyses of standards are in agreement with the recommended values. The platinum group elements (PGE) and Au contents were also determined with the ICP-MS at HKU. The pre-concentration followed combination of NiS fusion and Te co-precipitation (Sun et al., 1993; Zhou, 1994). Mass $108\left({ }^{108} \mathrm{Pd}\right)$ and mass $105\left({ }^{40} \mathrm{Ar}^{65} \mathrm{Cu}\right.$ and ${ }^{105} \mathrm{Pd}$ ) were determined in order to evaluate the contribution of ${ }^{40} \mathrm{Ar}^{65} \mathrm{Cu}$, so that ${ }^{63} \mathrm{Cu}^{40} \mathrm{Ar}$ interference with ${ }^{103} \mathrm{Rh}$ can be calculated $\left({ }^{103} \mathrm{Rh}\right.$ is the only isotope of Rh). Standard materials, WPR-1
Table 3. Trace element concentrations (ppm) of whole rock and mineral separates from the Dahongshan garnet lherzolite

\begin{tabular}{lrrrrr}
\hline & WR & CPX & \multicolumn{1}{c}{ GT } & OPX & OL \\
\hline $\mathrm{Ba}$ & 55.43 & 73.77 & 65.83 & 9.74 & nd \\
$\mathrm{Rb}$ & 2.49 & 2.75 & 5.58 & 2.37 & nd \\
$\mathrm{Sr}$ & 21.53 & 79.92 & 17.71 & 7.52 & nd \\
$\mathrm{La}$ & 2.49 & 5.29 & 1.04 & 0.63 & 0.019 \\
$\mathrm{Ce}$ & 3.88 & 12.59 & 1.70 & 1.10 & 0.032 \\
$\mathrm{Pr}$ & 0.36 & 1.43 & 0.22 & 0.12 & 0.003 \\
$\mathrm{Nd}$ & 1.04 & 4.49 & 1.10 & 0.44 & 0.013 \\
$\mathrm{Sm}$ & 0.12 & 0.56 & 0.37 & 0.10 & 0.003 \\
$\mathrm{Eu}$ & 0.04 & 0.16 & 0.17 & 0.03 & 0.001 \\
$\mathrm{Gd}$ & 0.17 & 0.43 & 0.98 & 0.13 & 0.003 \\
$\mathrm{~Tb}$ & 0.03 & 0.06 & 0.27 & 0.02 & $<0.001$ \\
$\mathrm{Dy}$ & 0.27 & 0.30 & 2.30 & 0.12 & 0.003 \\
$\mathrm{Ho}$ & 0.06 & 0.05 & 0.59 & 0.02 & nd \\
$\mathrm{Er}$ & 0.21 & 0.10 & 1.98 & 0.05 & nd \\
$\mathrm{Tm}$ & 0.03 & 0.01 & 0.34 & $<0.01$ & nd \\
$\mathrm{Yb}$ & 0.24 & 0.06 & 2.36 & 0.04 & nd \\
$\mathrm{Lu}$ & 0.04 & $<0.01$ & 0.40 & $<0.01$ & nd \\
$\mathrm{Y}$ & 1.55 & 1.17 & 3.37 & 0.61 & nd \\
$\mathrm{Zr}$ & 2.17 & 2.39 & 1.67 & 2.13 & nd \\
$\mathrm{Nb}$ & 1.33 & 1.62 & 0.49 & 0.63 & nd \\
\hline
\end{tabular}

nd indicates not detected. Rare earth element data in $O L$ are just for reference (ppt level).

and TDB-1, were analyzed and analytical uncertainties were better than $15 \%$ for $\mathrm{Ru}$ and $\mathrm{Rh}$, and $10 \%$ for Ir, Pd and Pt (Zhou et al., 2000). Os data are not reported, as it is difficult to avoid the loss of Os oxides during sample preparation. The results are presented in Table 4.

For $\mathrm{Rb}-\mathrm{Sr}$ and $\mathrm{Sm}-\mathrm{Nd}$ isotope analyses, sample powders were spiked with mixed ${ }^{87} \mathrm{Rb}-{ }^{84} \mathrm{Sr}$ and ${ }^{149} \mathrm{Sm}^{-146} \mathrm{Nd}$ tracers and dissolved in Teflon screw- 
Table 4. PGE concentration ( $p p b)$ in the Dahongshan garnet lherzolite

\begin{tabular}{llllllll}
\hline & $\mathrm{Ir}$ & $\mathrm{Ru}$ & $\mathrm{Rh}$ & $\mathrm{Pt}$ & $\mathrm{Pd}$ & $\mathrm{Au}$ & $\mathrm{Pd} / \mathrm{Ir}$ \\
\hline DHS & 3.60 & \multirow{2}{*}{4.86} & \multirow{2}{*}{1.36} & \multirow{2}{*}{9.66} & 9.18 & 11.3 & 2.55 \\
M7 & 8.2 & & & & 8.8 & 0.3 & 1.07 \\
M8 & 4.9 & & & & 1.0 & 0.08 & 0.20 \\
M11 & 6.2 & & & & 0.3 & 0.09 & 0.05 \\
M12 & 8.5 & & & & 1.6 & 0.2 & 0.19 \\
\hline
\end{tabular}

DHS is the Dahongshan lherzolite. M7, M8, M11, and M12 are garnet lherzolites from the Matsoku kimberlites, Lesotho (Mitchell and Keays, 1981).

Table 5. Sr and Nd isotopes of the Dahongshan garnet lherzolite and its mineral separates

\begin{tabular}{lcccccccccc}
\hline & ${ }^{87} \mathrm{Rb} /{ }^{86} \mathrm{Sr}$ & ${ }^{87} \mathrm{Sr} /{ }^{86} \mathrm{Sr}$ & $\pm 2 \sigma$ & $\varepsilon_{\mathrm{Sr} 510}$ & $\varepsilon_{\mathrm{Sr} 326}$ & ${ }^{147} \mathrm{Sm} /{ }^{144} \mathrm{Nd}$ & ${ }^{143} \mathrm{Nd} /{ }^{144} \mathrm{Nd}$ & $\pm 2 \sigma$ & $\varepsilon_{\mathrm{Nd} 510}$ & $\varepsilon_{\mathrm{Nd} 326}$ \\
\hline WR & 0.3344 & 0.706614 & 10 & 4.25 & 13.57 & & & & & \\
CPX & 0.0995 & 0.704844 & 14 & 3.36 & 3.91 & 0.0754 & 0.512011 & 10 & -4.33 & -7.19 \\
GT & 0.9109 & 0.711011 & 10 & 7.19 & 38.03 & 0.2033 & 0.512427 & 9 & -4.55 & -4.40 \\
OPX & 0.9111 & 0.710610 & 14 & 1.47 & 32.32 & 0.1374 & 0.512148 & 38 & -5.70 & -7.10 \\
\hline
\end{tabular}

Chondrite Uniform Reservoir (CHUR) values $\left({ }^{87} \mathrm{Rb} /{ }^{86} \mathrm{Sr}=0.0847,{ }^{87} \mathrm{Sr} /{ }^{86} \mathrm{Sr}=0.7045,{ }^{147} \mathrm{Sm} /{ }^{144} \mathrm{Nd}=0.1967,{ }^{143} \mathrm{Nd} /{ }^{144} \mathrm{Nd}=\right.$ $0.512638)$ are used for the calculation. $\lambda_{R b}=1.42 \times 10^{-11}$ year ${ }^{-1}$ (Steiger and Jäger, 1977); $\lambda_{S m}=6.54 \times 10^{-12}$ year ${ }^{-1}($ Lugmair and Marti, 1978).

cap capsules at sub-boiling temperature for one week with $\mathrm{HF}+\mathrm{HNO}_{3}$ acid. After complete dissolution, the solution was dried and the residue was then re-dissolved with $\mathrm{HClO}_{4}$ to get rid of $\mathrm{HF}$. The solution was dried again and added little bit $6 \mathrm{~N}$ $\mathrm{HCl}$. Finally the sample was dissolved in $1.75 \mathrm{~N}$ $\mathrm{HCl}$. The $\mathrm{Rb}, \mathrm{Sr}$ and the REE were separated by conventional cation-exchange techniques $\left(\mathrm{AG} 50 \mathrm{~W} \times 8\left(\mathrm{H}^{+}\right)\right.$risen) with $2.5 \mathrm{~N}$ and $4 \mathrm{~N} \mathrm{HCl}$ as eluant. The separation of $\mathrm{Sm}$ and $\mathrm{Nd}$ from the bulk REE was performed on small quartz glass columns using KEL-F powder coated di-orthophosphoric acid (HDEHP) and $0.17 \mathrm{~N}$ and $0.4 \mathrm{~N} \mathrm{HCl}$ as eluant. $\mathrm{Rb}, \mathrm{Sr}, \mathrm{Sm}$, and $\mathrm{Nd}$ isotopic compositions were measured with a VG-354 mass-spectrometer at IGG. The analytical methods followed Qiao (1987). For $\mathrm{Sr}$ and $\mathrm{Nd}$ isotopic ratios, the mass fractionation corrections were based on ${ }^{86} \mathrm{Sr} /{ }^{88} \mathrm{Sr}=0.1194$ and ${ }^{145} \mathrm{Nd} /{ }^{144} \mathrm{Nd}=0.348412$ (corresponding to ${ }^{146} \mathrm{Nd} /{ }^{144} \mathrm{Nd}=0.7219$ ), respectively. Over the period of analytical work, repeat analyses yielded an ${ }^{87} \mathrm{Sr} /{ }^{86} \mathrm{Sr}$ ratio of $0.71023 \pm 4$ for the NBS-987 Sr standard and a ${ }^{143} \mathrm{Nd} /{ }^{144} \mathrm{Nd}$ ratio of $0.511845 \pm 12$ for the La Jolla standard. Total blanks for $\mathrm{Rb}, \mathrm{Sr}, \mathrm{Sm}$ and $\mathrm{Nd}$ were less than $100 \mathrm{pg}$. The results are given in Table 5. Errorchron ages were calculated using the York regression program (Ludwig, 1991).

\section{RESULTS}

Major element chemistry

The Dahongshan garnet lherzolite xenolith possesses $44.3 \mathrm{wt} \% \mathrm{SiO}_{2}, 40.9 \mathrm{wt} \% \mathrm{MgO}, 2.82 \mathrm{wt} \%$ $\mathrm{CaO}$ and $2.66 \mathrm{wt} \% \mathrm{Al}_{2} \mathrm{O}_{3}$. This shows that the xenolith was derived from a depleted mantle source. However, compared with the average composition of global kimberlite-borne garnet lherzolites from old cratonic lithosphere mantle (McDonough, 1994), the xenolith in this study has relatively high $\mathrm{Al}_{2} \mathrm{O}_{3}$ and $\mathrm{CaO}$ contents and low $\mathrm{MgO}$ content (Table 2), indicating a less depleted mantle source.

Individual granuloblastic minerals in the 

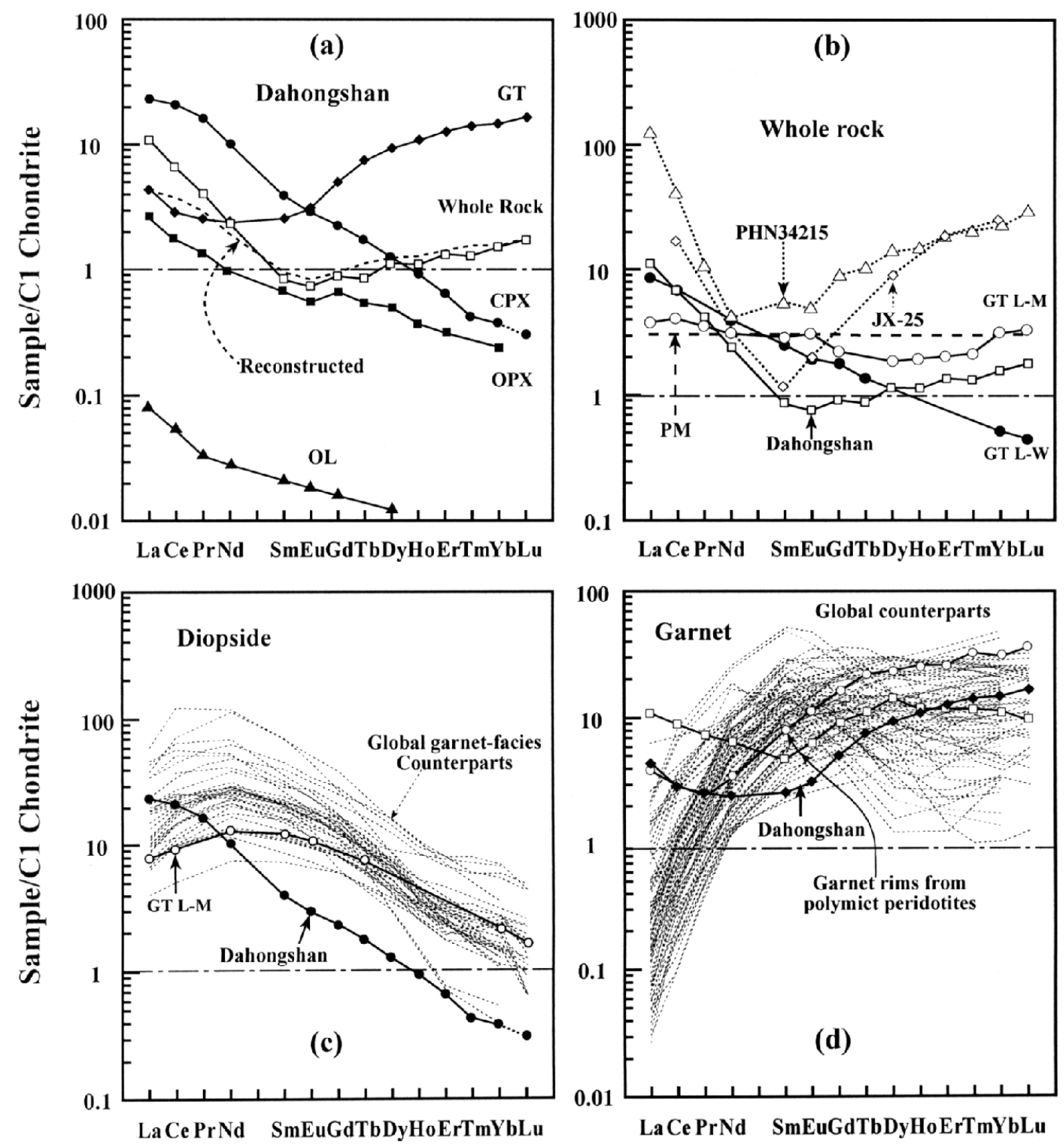

Fig. 3. Chondrite-normalized REE diagrams for whole rock and mineral separates from the Dahongshan garnet lherzolite. Normalization values are those from Anders and Grevesse (1989). Dashed line is for the data reconstructed from the mineral modes and compositions. Note that the reconstructed REE abundances are quite consistent with the measured values, especially MREE-HREEs. (a): The Dahongshan lherzolite and its mineral separates; (b): Comparison of the Dahongshan lherzolite with its counterparts; (c): Diopside; (d): Garnet. GT L-W and GT L-M represent the average REE abundances in garnet lherzolites from worldwide kimberlites (McDonough, 1994) and from Mingxi Cenozoic basalts, respectively (Liu et al., 1985; Huang et al., 1992; Qi et al., 1995). JX25 is a garnet lherzolite from the Jagersfontein kimberlites (Macdougall and Haggerty, 1999), which is considered to be derived from transitional zone. PHN34215 is an eclogite from the Bellsbank kimberlite (Jerde et al., 1993) and shows the exsolution of Gt and Opx within the Cpx. Global garnet-facies peridotitic diopsides and garnets are taken from Hoal et al. (1994) and Zhang (1998). Garnet rim in a polymict peridotite is from Zhang et al. (2000b). 
lherzolite xenolith are generally homogenous in major element compositions and the same minerals have uniform compositions among different grains (Table 1) except for one garnet grain in which the core shows slightly higher $\mathrm{Cr}_{2} \mathrm{O}_{3}$ and $\mathrm{CaO}$ contents than the rim. Olivine has Fo values of 90.5 with high $\mathrm{NiO}$ content around $0.49 \mathrm{wt} \%$. Orthopyroxene is slightly low in $\mathrm{Al}_{2} \mathrm{O}_{3}(\leq 1.7 \%)$ and $\mathrm{CaO}(\leq 0.6 \%)$ contents with En values of $\sim 91 \%$. Clinopyroxene is $\mathrm{Cr}$-diopsidic and slightly low in $\mathrm{Al}_{2} \mathrm{O}_{3}, \mathrm{FeO}$, and $\mathrm{Na}_{2} \mathrm{O}$ and high in $\mathrm{MgO}$ (Table 1). Garnet is Cr-pyrope and belongs to Group 9 according to the classification of Dawson and Stephens (1976). These garnets have $\mathrm{MgO}$ and $\mathrm{Cr}_{2} \mathrm{O}_{3}$ contents lower than those for the garnets from the kimberlite-borne mantle xenoliths from other cratons in the world (Nixon, 1987). A finegrained garnet in the groundmass has higher $\mathrm{CaO}$, $\mathrm{TiO}_{2}$, and $\mathrm{Na}_{2} \mathrm{O}$, and lower $\mathrm{MgO}, \mathrm{FeO}$, and $\mathrm{Al}_{2} \mathrm{O}_{3}$ than the granuloblastic ones, but with about the same concentration of $\mathrm{Cr}_{2} \mathrm{O}_{3}$ (Table 1).

\section{Trace element and PGE geochemistry}

The Dahongshan garnet lherzolite xenolith clearly shows a "V"-shape Chondrite-normalized REE pattern (Figs. 3(a) and (b)), i.e., LREEs are enriched $\left((\mathrm{La} / \mathrm{Sm})_{\mathrm{N}}=13\right)$, but MREEs are depleted $\left((\mathrm{Eu} / \mathrm{Yb})_{\mathrm{N}}=0.48\right)$. This V-shape REE pattern is considerably different from the general LREE-enriched patterns $\left((\mathrm{La} / \mathrm{Yb})_{\mathrm{N}}=16.7\right)$ for the garnet peridotite xenoliths from the kimberlites on other cratons in the world (Fig. 3(b)).

Diopside from this xenolith shows a strong REE fractionation $\left((\mathrm{La} / \mathrm{Yb})_{\mathrm{N}}=61\right)$, its M-HREEs are extremely depleted when compared with its global counterparts (Fig. 3(c)). In addition, the diopside mineral in this study does not show a convex-upward pattern which is common for diopsides from garnet-facies mantle peridotites in the world (Menzies et al., 1987; Qi et al., 1995; Zhang, 1998). Orthopyroxene and olivine also have LREE-enriched patterns (Fig. 3(a)), which are not supportive of a residual origin.

Garnet shows a peculiar "spoon"-shaped REE pattern (Figs. 3(a) and (d)), in remarkable contrast with the well-documented two types of REE patterns for its global counterparts: LREE-depleted or sinusoidal patterns (e.g., Hoal et al., 1994; Zhang, 1998).

The Dahongshan lherzolite xenolith and its constituent minerals (e.g., Cpx and Gt) are enriched in LILE (e.g., Ba, Rb) and depleted in HFSE (e.g., $\mathrm{Zr}, \mathrm{Ti}$ ) relative to the primitive mantle, showing pronounced negative $\mathrm{Zr}$ and $\mathrm{Nb}$ anomalies in the trace element spidergram (Fig. 4). Negative $\mathrm{Ti}$ anomaly is present in the garnet. Opx has low contents of almost all LILEs and HFSEs except for $\mathrm{Ba}$ and $\mathrm{Rb}$ that are slightly higher than the values of the primitive mantle. PGE and Ni contents in the lherzolite xenolith are very close

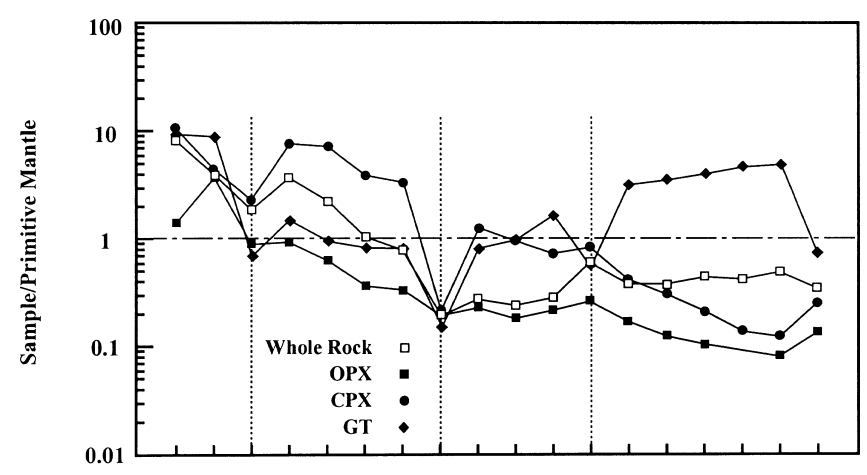

Ba Rb Nb La Ce Sr Nd Zr Sm Eu Gd Ti Dy Ho Er Tm Yb Y

Fig. 4. Primitive mantle-normalized trace element diagrams for the Dahongshan garnet lherzolite and its mineral separates. Primitive mantle values are from Sun and McDonough (1989). 
(PGE $=0.8-2.2$ times) to the abundance of the primitive mantle (Barnes et al., 1988) with slight fractionation of PGE $(\mathrm{Pd} / \mathrm{Ir}=2.55$, Table 4 and Fig. 5). The Pd/Ir ratio for the Dahongshan lherzolite is higher than that for the garnet lherzolite from Matsoku kimberlites (Table 4;

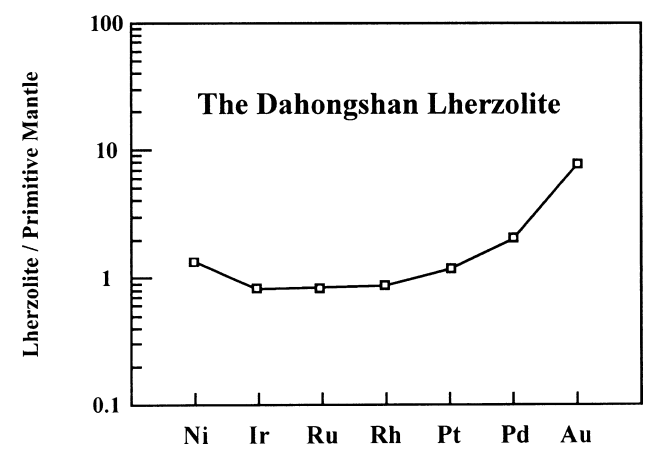

Fig. 5. Primitive mantle-normalized PGE and related element diagram for the Dahongshan garnet lherzolite. Primitive mantle values are from Barnes et al. (1988): Ni 1950 ppm, Ir 4.4 ppb, Ru 5.6 ppb, Rh 1.6 ppb, Pt 8.3 ppb, Pd $4.4 \mathrm{ppb}$, and Au $1.4 \mathrm{ppb}$.
Mitchell and Keays, 1981), which is again indicative of the less depletion.

\section{Sr-Nd isotopic compositions}

The $\mathrm{Sr}$ and $\mathrm{Nd}$ isotopic compositions of the lherzolite xenolith and its mineral separates all show enriched characteristics $\left(\varepsilon_{\mathrm{Sr}}\right.$ and $\varepsilon_{\mathrm{Nd}}$ values are 3.91 to 38.03 and -4.40 to -7.19 , respectively, at the kimberlite eruption (326 Ma)) (Table 5, Fig. 6). The garnet yields identical ${ }^{87} \mathrm{Rb} /{ }^{86} \mathrm{Sr}$ ratio to the orthopyroxene, but its ${ }^{87} \mathrm{Sr} /{ }^{86} \mathrm{Sr}$ ratio is slightly higher than that of orthopyroxene. This could be due to a small degree of isotopic resetting for the orthopyroxene. Regression of whole rock and CPX, GT, OPX mineral separates gives a line in the $\mathrm{Rb}$-Sr errorchron diagram, which corresponds to $519 \mathrm{Ma}$ with a very large error $( \pm 52 \mathrm{Ma})$ and an initial ${ }^{87} \mathrm{Sr} /{ }^{86} \mathrm{Sr}$ ratio of $0.70412 \pm 0.00006$ (Fig. 7). Sm-Nd isotopic data do not define an isochron, regression of clinopyroxene, orthopyroxene and garnet mineral data gives a line corresponding to $498 \pm 15 \mathrm{Ma}$ with an initial ${ }^{143} \mathrm{Nd} /{ }^{144} \mathrm{Nd}$ ratio of $0.51174 \pm 0.00005$ (Fig. 7).

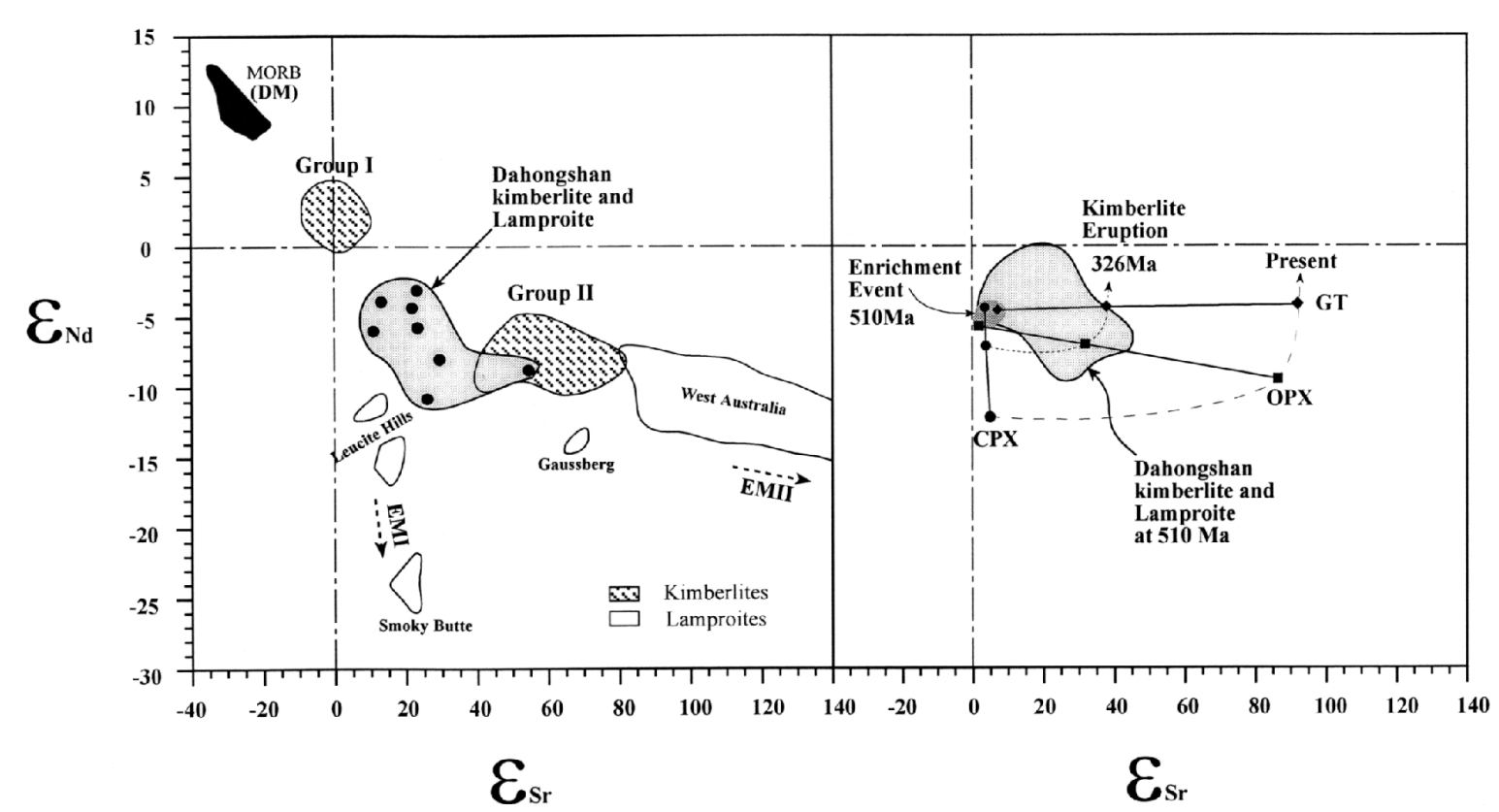

Fig. 6. Sr and Nd isotopic diagram for the Dahongshan lherzolite and its mineral separates, compared with host kimberlites and lamproites and global counterparts (Liu et al., 1993; Hawkesworth et al., 1990). 

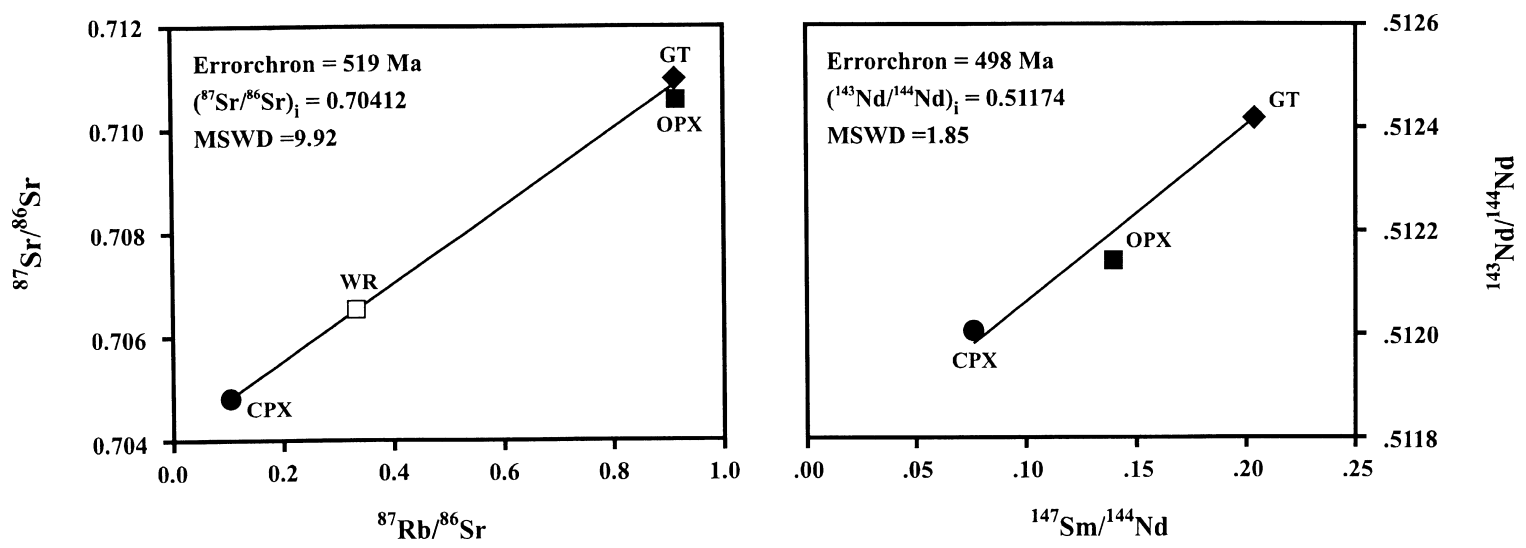

Fig. 7. Rb-Sr and Sm-Nd errorchron diagram for the Dahongshan lherzolite and its mineral separates. Errorchron age was calculated using the York regression program (Ludwig, 1991).

\section{DISCUSSION}

Mantle processes recorded in the lherzolite xenolith

Geochemical and isotopic data suggest that the Dahongshan garnet lherzolite from the Yangtze Craton was affected by at least two mantle processes before its incorporation into the host Paleozoic kimberlite: depletion followed by an enrichment.

Depletion process Several aspects of the Dahongshan lherzolite xenolith indicate an early partial melting process in its mantle source. Although less depleted than the kimberlite-borne garnet lherzolite xenoliths from old cratonic lithosphere (Nixon, 1987; Jaques et al., 1990; McDonough, 1994; Zheng and Lu, 1999), the relatively high $\mathrm{Mg}(\mathrm{Mg} \#=90.9 \%)$ and $\mathrm{NiO}(0.33 \mathrm{wt} \%$, Table 2) and low $\mathrm{CaO}(2.82 \mathrm{wt} \%)$ and $\mathrm{Al}_{2} \mathrm{O}_{3}$ $(2.66 \mathrm{wt} \%)$, compared with the primitive mantle (McDonough, 1994), suggest that the Dahongshan lherzolite may represent the refractory residue after a previous melt extraction (e.g., Frey and Prinz, 1978; McDonough, 1990). This is further demonstrated by the high Fo and $\mathrm{NiO}$ contents in olivine minerals (Table 1).

Trace element data also support this depletion process. The lherzolite from the Dahongshan kimberlite has a V-shaped Chondrite-normalized REE pattern. The depletion in MREE
$\left((\mathrm{Eu} / \mathrm{Yb})_{\mathrm{N}}=0.48\right.$; Fig. 3(b)) can be interpreted in terms of melt extraction with loss of the incompatible elements. This is also manifested by the relatively high $\mathrm{PGE}$ contents and the $\mathrm{Pd} / \mathrm{Ir}$ fractionation (Table 4 and Fig. 5). The slight enrichment of Pd-group PGE from primitive mantle may imply a moderate depletion (Fig. 5).

There is no other report on garnet lherzolite xenoliths from the Yangtze Craton, but the counterparts exist in the Paleozoic kimberlites on the North China Craton and in the Cenozoic alkaline basalts erupted on the Cathaysia Block, Southeastern China (Fig. 1). The former rocks are seriously altered, but $\mathrm{Al}_{2} \mathrm{O}_{3}$ and $\mathrm{CaO}$ data still show highly depleted nature (Zheng and Lu, 1999; Lu et al., 2000). The Cenozoic basalt-borne garnet lherzolites from the Cathaysia Block (Mingxi, Fujian Province of China) have much higher $\mathrm{Al}_{2} \mathrm{O}_{3}$ and $\mathrm{CaO}$ contents and lower $\mathrm{MgO}$ than the Dahongshan garnet lherzolite (Liu et al., 1985; Huang et al., 1992; Qi et al., 1995), almost equivalent to the primitive mantle compositions (McDonough, 1994). Their REE abundances are also similar to those for the primitive mantle, but are slightly LREE-enriched (Fig. 3(b)).

Enrichment process The Dahongshan lherzolite xenolith shows a V-shape REE pattern, garnet separates have spoon-shape patterns and other constituent minerals, $\mathrm{Cpx}$, Opx and $\mathrm{Ol}$, are all LREE enriched (Fig. 3). These features indicate 
an enrichment process in the mantle source, which postdated an early event of melt extraction. The V-shape REE patterns were previously reported for two reconstructed whole rock compositions based on mineral modes and mineral REE contents (Fig. 3(b)): one is a garnet lherzolite from the Jagersfontein kimberlites (Macdougall and Haggerty, 1999) and the other is an eclogite from the Bellsbank kimberlites (Jerde et al., 1993). Both were considered to have an ultra-deep origin and were interpreted as results of metasomatic enrichment.

The spoon-shape REE pattern for garnet was previously reported only for the rims of garnet from a polymict peridotite from South Africa, which was attributed to a recent metasomatism (Zhang et al., 2000b). The garnet separates from the Dahongshan lherzolite xenolith consistently show the spoon-shape REE patterns throughout the mineral. Therefore, the enrichment must be an event prior to the kimberlite eruption in the mantle. Similar REE patterns were also reported for a few clinopyroxene minerals from spinel-facies mantle peridotites (e.g., Sen et al., 1993; Zangana et al., 1997; Fan et al., 2000), which was accounted for as the result of small-volume melt infiltration into the grain (Navon and Stolper, 1987; $\mathrm{Xu}$ et al., 1998). High permeability of La and Ce may lead to their enrichments relative to other LREE (Pr, Nd, Sm) (Navon and Stolper, 1987). Here we tentatively consider melt infiltration in the mantle at the garnet-facies depth as the cause of the spoon-shape REE patterns for the garnet separates. Extensive melt filtration may also account for the high LREE enrichment in clinopyroxene $\left((\mathrm{La} / \mathrm{Yb})_{\mathrm{N}}=61\right.$; Fig. 3(c) $)$ and its high modal proportion in the xenolith. One may question whether trapped melt/fluid inclusions exist in the constituent minerals and are responsible for the enrichment. Our petrographic study did not favor such an interpretation, because no visible melt/fluid inclusions were observed.

The enrichment in the lherzolite xenolith is further demonstrated by $\mathrm{Sr}-\mathrm{Nd}$ isotopic compositions (Fig. 6). Although no isochrons were defined by our results, the $\mathrm{Rb}-\mathrm{Sr}$ and $\mathrm{Sm}-\mathrm{Nd}$ data show a
519 and a 498 Ma trends, respectively, both much older than the age of the host kimberlite $(\sim 326$ Ma). This may imply that the enrichment event happened prior to the kimberlite eruption. The lamproites on the centre of the Yangtze Craton have a similar age of $510 \mathrm{Ma}$ (Liu et al., 1993). When $\mathrm{Sr}$ and $\mathrm{Nd}$ isotopic ratios are extrapolated to $510 \mathrm{Ma}$, the xenolith whole rock and mineral separates converge at a uniform isotopic composition $\left(\varepsilon_{\mathrm{Sr}} \approx 4.06 ; \varepsilon_{\mathrm{Nd}} \approx-4.86\right)$. This may imply that mantle enrichment event indeed happened at $\sim 510 \mathrm{Ma}$, prior to the kimberlite eruption, and was related to the magmatic activity of the lamproites on the Yangtze Craton. These lamproites are all enriched in LREE and LILE and depleted in HFSE such as Zr (Liu et al., 1993).

\section{Nature of the lithospheric mantle beneath the Yangtze Craton}

The Dahongshan lherzolite xenolith shows a less depleted feature in major element composition than its counterparts from the North China Craton and other old cratons in the world (Nixon, 1987; Jaques et al., 1990; McDonough, 1994; Zheng and Lu, 1999). This may reflect modification of the Dahongshan xenolith by melt infiltration, or alternatively may indicate that the Proterozoic lithosphere beneath the Yangtze Craton chemically differs from the typical continental lithospheric mantle beneath the Archaean cratons such as the Kaapvaal, the Siberia, and the North China Craton.

Textural relationship and compositional homogeneity in mineral grains indicate that the chemical equilibrium was reached in the Dahongshan lherzolite xenolith, although the rock was infiltrated by the LREE- and LILE-rich melt. The stable Gt-Opx-Cpx mineral assemblage gives a temperature-pressure estimation of $1042^{\circ} \mathrm{C}$ and 34 kbar, corresponding to a depth of $110 \mathrm{~km}$, for the lherzolite xenolith (Fig. 8; Bertrand and Mercier, 1986; Nickel and Green, 1985). The geotherm inferred from this result is much higher than the typical cratonic geotherm $\left(40 \mathrm{~mW} / \mathrm{m}^{2}\right)$, but lower than the oceanic geotherm. This may imply that the mantle source in the region was hotter in the 


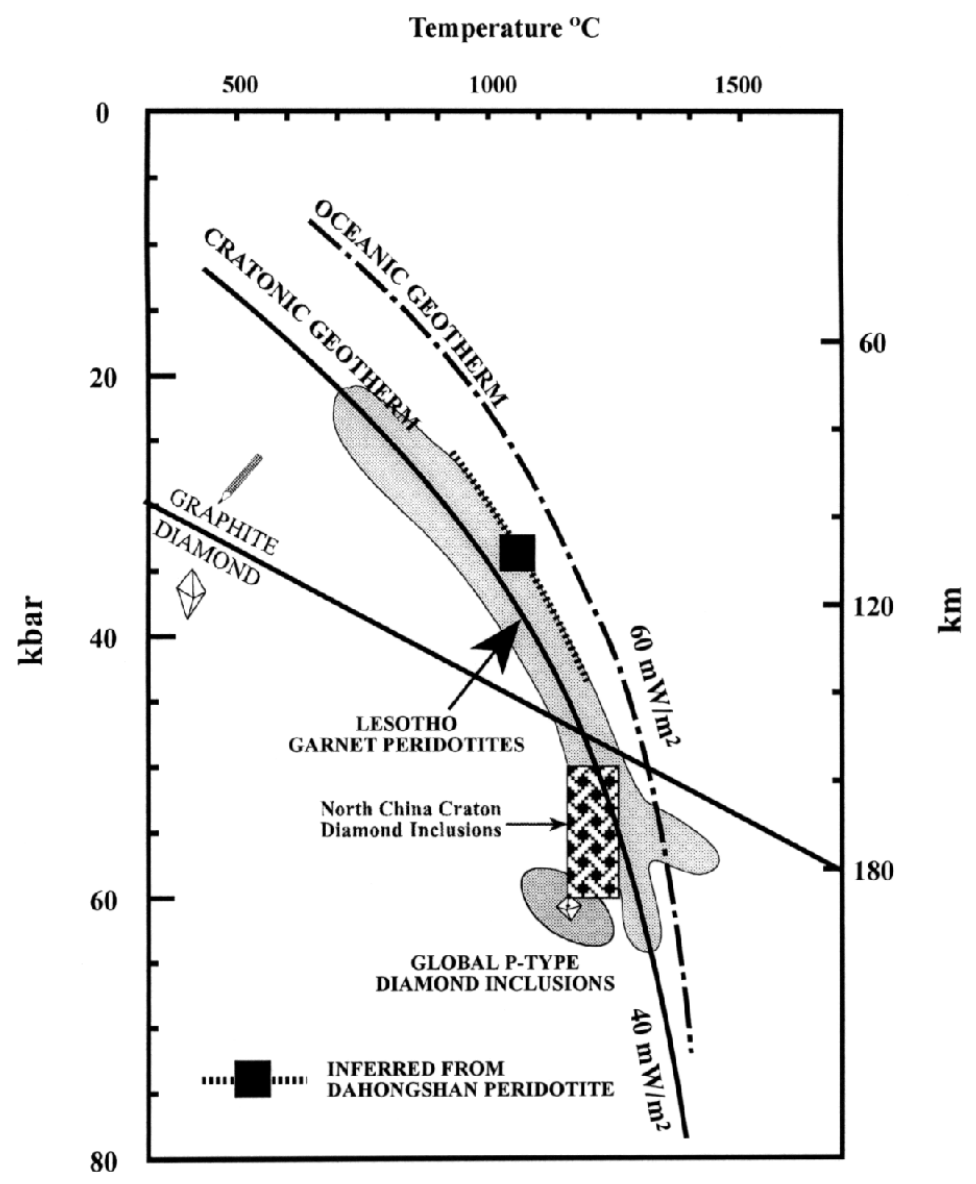

Fig. 8. The geotherm derived from the Dahongshan garnet lherzolite, compared with typical cratonic and oceanic geotherms (Menzies and Chazot, 1995). T-P in Chinese diamond inclusions from the North China Craton was calculated from the original data of Harris et al. (1994) and Meyer et al. (1994). All other data are from Menzies and Chazot (1995) and references therein. Note that the geotherm inferred from the Dahongshan lherzolite plots between the typical cratonic and oceanic geotherms.

Paleozoic (Zhou et al., 1994). The barren feature of the Dahongshan kimberlite indicates that the thickness of the lithosphere in the northern margin of the Yangtze Craton was less than $150 \mathrm{~km}$ at the time of kimberlite eruption, within the graphite stability field (Fig. 9). The presence of the diamond-bearing lamproites in the central part of the Yangtze Craton (e.g., Zhengyuan and Ningxiang) indicates that the lithosphere in these areas was more than $150 \mathrm{~km}$ deep (Fig. 9). The coupled trace element and $\mathrm{Sr}-\mathrm{Nd}$ isotopic compositions indicate that these lamproites were originated from an enriched mantle (Liu et al., 1993). Although no more detailed study has been undertaken on these rocks, the presence of these lamproites generally requires a metasomatised phlogopite harzburgite as source materials (Mitchell and Bergman, 1991). Previous investigations on the mantle xenoliths from the old cratons revealed that the lithospheric mantle is highly heterogeneous not only horizontally but also vertically, in terms of major and trace element compositions and isotopic ratios (Nixon, 1987; Hoal et al., 1994; Carlson and Irving, 1994; Pearson et al., 1994, 1995; Wang et al., 1998). The heterogeneous nature of the lithospheric mantle and scarcity of data from the Yangtze Craton 


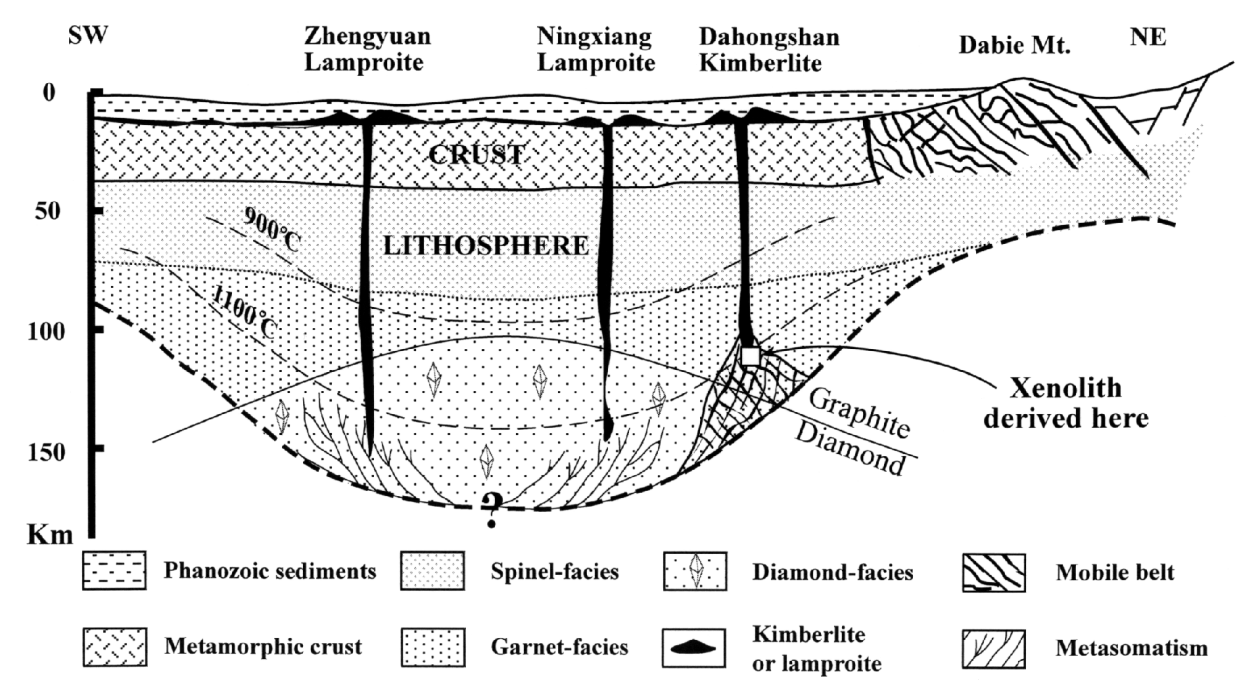

Fig. 9. Schematic drawing to show the cross-section of the continental lithosphere beneath the Yangtze Craton, modeling the origin of kimberlites and lamproites by partial melting of potentially enriched mantle source (modified from Liu et al. (1993) and Haggerty (1986)). The thick dash line indicates the base of the lithosphere which is poorly constrained at this stage.

make its comparison with the lithosphere in other regions premature at present. However, data from this study as well as from previous studies indicate that the lithospheric mantle beneath the Yangtze Craton was possibly less depleted and was hotter in Paleozoic than the lithospheric mantle beneath the NCC.

\section{CONCLUdiNG REMARKS}

The mantle xenolith from the Dahongshan kimberlite is moderately depleted in major oxides such as $\mathrm{Al}_{2} \mathrm{O}_{3}$ and $\mathrm{CaO}$ but considerably enriched in trace elements (e.g., LREE and LILE). This suggests that the mantle source underwent at least two different processes: melt extraction followed by enrichment. Melt infiltration was invoked as the cause of trace element enrichments. $\mathrm{Rb}-\mathrm{Sr}$ and $\mathrm{Sm}-\mathrm{Nd}$ isotopic data favor an interpretation that the enrichment event happened about $510 \mathrm{Ma}$ ago, possibly corresponding to the lamproitic magmatic activity in the Yangtze Craton. The lithospheric mantle beneath the Yangtze Craton may be less depleted and hotter in Paleozoic than the lithospheric mantle beneath the NCC.
Acknowledgments-A Sino-British Fellowship to HFZ is gratefully acknowledged, which supported his collaborative research at the University of Hong Kong. We are also grateful to Mr. Au Dipwa, Dr. Xu P., Mrs. Liu Y., and Mr. Zhang R.-H. for technical assistance in sample preparation, electron probe, ICP-MS, and Sr$\mathrm{Nd}$ isotopic analyses. This work was financially supported by Chinese National Science Foundation (49733110), Hong Kong RGC grant (HKU7110/97P), Chinese Academy of Sciences (KZCX1-07), Chinese 973 Project (G1999075504). Special thanks are given to Drs. Koshi Yamamoto, Tomoharu Miyamoto, and Cristian Dragusanu for careful review.

\section{REFERENCES}

Anders, E. and Grevesse, N. (1989) Abundances of the elements: meteoritic and solar. Geochim. Cosmochim. Acta 53, 197-214.

Barnes, S. J., Boyd, R., Korneliussen, A., Nilsson, L. P., Often, M., Pederson, R. B. and Robins, B. (1988) The use of mantle normalization and metal ratios in discriminating between the effects of partial melting, crystal fractionation and sulfide segregation on platinum-group elements, gold, nickel and copper: examples from Norway. Geo-platinum 87 (Prichard, H. M., Potts, P. J., Bowles, J. F. W. and Cribb, S. J., eds.), 113-143, Elsevier Press.

Bertrand, P. and Mercier, J.-C.C. (1986) The mutual 
solubility of coexisting ortho- and clinopyroxene: toward an absolute geothermometer for the natural system? Earth Planet. Sci. Lett. 76, 109-122.

Carlson, R. W. and Irving, A. J. (1994) Depletion and enrichment history of subcontinental lithospheric mantle: an $\mathrm{Os}, \mathrm{Sr}, \mathrm{Nd}$ and $\mathrm{Pb}$ isotopic study of ultramafic xenolith from the Northwestern Wyoming Craton. Earth Planet. Sci. Lett. 126, 457-472.

Dawson, J. B. (1980) Kimberlites and Their Xenoliths. Springer Verlag Press, $252 \mathrm{pp}$.

Dawson, J. B. and Stephens, W. E. (1976) Statistical classification of garnets from kimberlite and associated xenoliths-addendum. J. Geol. 84, 495-496.

Fan, W.-M., Zhang, H.-F., Baker, J., Jarvis, K. E., Mason, P. R. D. and Menzies, M. A. (2000) On and off the North China Craton: where is the Archaean keel? J. Petrol. 41, 933-950.

Frey, F. A. and Prinz, M. (1978) Ultramafic inclusions from San Carlos, Arizona: petrologic and geochemical data bearing on their petrogenesis. Earth Planet. Sci. Lett. 38, 129-176.

Griffin, W. L., O'Reilly, S. Y. and Hollis, J. D. (1984) Ultramafic xenoliths from Bullenmerri and Gnotuk maars, Victoria, Australia: petrology of a sub-continental crust-mantle transition. J. Petrol. 25, 53-87.

Griffin, W. L., O'Reilly, S. Y. and Ryan, C. G. (1992) Composition and thermal structure of the lithosphere beneath South Africa, Siberia and China: proton microprobe studies (abstract). International Symposium on Cenozoic Volcanic Rocks and Deep-Seated Xenoliths of China and Its Environs, Beijing, A65A66.

Haggerty, S. E. (1986) Diamond genesis in a multiplyconstrained model. Nature 320, 34-48.

Harris, J. W., Duncan, D. J., Zhang, F., Miao, Q. and Zhu, Y. (1994) The physical characteristics and syngenetic inclusion geochemistry of diamonds from Pipe 50, Liaoning province, People's Republic of China. Proc. Int. Kimb. Conf. (vol. 2) 5th, 106-115.

Hawkesworth, C. J., Kempton, P. D., Rogers, N. W., Ellam, R. M. and Van Calstern, P. W. (1990) Continental mantle lithosphere, and shallow level enrichment processes in the Earth's mantle. Earth Planet. Sci. Lett. 96, 256-268.

Hoal, K. E. O., Hoal, B. G., Erlank, A. J. and Shimizu, N. (1994) Metasomatism of the mantle lithosphere recorded by rare earth elements in garnets. Earth Planet. Sci. Lett. 126, 303-313.

Huang, W.-K., Wang, J.-W., Basu, A. R. and Tatsumoto, M. (1992) REE and Pb-Sr-Nd isotopic studies on garnet lherzolite xenoliths from Mingxi, Fujian Province. Geochimica 2, 101-111 (in Chinese).

Jaques, A. L., O'Neill, H. S. C., Smith, C. B., Moon, J. and Chappell, B. W. (1990) Diamondiferous peridotite xenoliths from the Argyle (AK1) lamproite pipe, Western Australia. Contrib. Mineral. Petrol. 104, 255-276.

Jerde, E. A., Taylor, L. A., Crozaz, G. and Sobolev, N. V. (1993) Exsolution of garnet within clinopyroxene of mantle eclogites: major- and trace-element chemistry. Contrib. Mineral. Petrol. 114, 148-159.

Liu, G.-L., Wang, X.-W. and Lü, X.-M. (1993) Dahongshan Lamproites. Geological Publishing House, Beijing, 186 pp. (in Chinese with English abstract).

Liu, R.-X., Fan, Q.-C. and Sun, J.-Z. (1985) Research on garnet lherzolites from several localities, China. Acta Petrologica Sinica 1(4), 24-33 (in Chinese).

Liu, Y.-S. and Zhao, C.-H. (1991) The first discovery of fresh garnet lherzolite nodule from Pengjiabang kimberlite pipe in the Dahongshan area, Hubei Province. Geological Science and Technology Information 10, Supplement, 109-116 (in Chinese).

Lu, F.-X., Zheng, J.-P., Li, W.-P., Chen, M.-H. and Chen, Z.-M. (2000) The main evolution pattern of Phanerozoic mantle in the eastern China: a "mushroom cloud" model. Earth Science Frontiers 7(1), 97-107 (in Chinese with English abstract).

Ludwig, K. R. (1991) ISOPLOT: a plotting and regression program for radiogenic-isotope data (version 2.53). Open File Report-U.S. Geological Survey, $39 \mathrm{pp}$.

Lugmair, G. W. and Marti, K. (1978) Lunar initial ${ }^{143} \mathrm{Nd} /{ }^{144} \mathrm{Nd}$ : differential evolution of the lunar crust and mantle. Earth Planet. Sci. Lett. 39, 349-357.

Macdougall, J. D. and Haggerty, S. E. (1999) Ultradeep xenoliths from African kimberlites: $\mathrm{Sr}$ and $\mathrm{Nd}$ isotopic compositions suggest complex history. Earth Planet. Sci. Lett. 170, 73-92.

McDonough, W. F. (1990) Constraints on the composition of the continental lithospheric mantle. Earth Planet. Sci. Lett. 101, 1-18.

McDonough, W. F. (1994) Chemical and isotopic systematics of continental lithospheric mantle. Proc. Int. Kimb. Conf. (vol. 1) 5th, 478-485.

Menzies, M. A. and Chazot, G. (1995) Fluid processes in diamond to spinel facies shallow mantle. $J$. Geodynamics 20, 387-415.

Menzies, M. A. and Hawkesworth, C. J. (1987) Mantle Metasomatism. Academic Press, 470 pp.

Menzies, M. A., Rogers, N., Tindle, A. and Hawkesworth, C. J. (1987) Metasomatic and enrichment processes in lithospheric peridotites, an effect of asthenosphere-lithosphere interaction. Mantle Metasomatism (Menzies, M. A. and Hawkesworth, C. J., eds.), 313-361, Academic Press.

Menzies, M. A., Fan, W. M. and Zhang, M. (1993) Paleozoic and Cenozoic lithoprobes and the loss of 
$>120 \mathrm{~km}$ of Archaean lithosphere, Sino-Korean Craton, China. Geol. Soc. Spel. Pub. 76, 71-78.

Meyer, H. O. A., Zhang, A., Milledge, H. J. and Mendelssohn, M.J. (1994) Diamonds and inclusions in diamonds from Chinese kimberlites. Proc. Int. Kimb. Conf. (vol. 2) 5th, 98-105.

Mitchell, R. H. and Bergman, S. C. (1991) Petrology of Lamproites. Plenum Press, $447 \mathrm{pp}$.

Mitchell, R. H. and Keays, R. R. (1981) Abundance of gold, palladium and iridium in some spinel and garnet lherzolites: implications for the nature of origin of precious metal-rich intergranular components in the upper mantle. Geochim. Cosmochim. Acta 45, 2425-2442.

Navon, O. and Stolper, E. (1987) Geochemical consequence of melt percolation: the upper mantle as a chromatographic column. J. Geol. 95, 285-307.

Nickel, H. G. and Green, D. H. (1985) Empirical geothermobarometry for garnet peridotites and implications for the nature of the lithosphere, kimberlites and diamonds. Earth Planet. Sci. Lett. 73, $158-170$.

Nixon, P. H. (1987) Mantle Xenoliths. John Wiley \& Sons Ltd, 846 pp.

Pearson, D. G., Boyd, F. R., Hoal, K. E. O., Hoal, B. G., Nixon, P. H. and Rogers, N. W. (1994) A Re-Os isotopic and petrological study of Namibian peridotites; contrasting petrogenesis and composition of on- and off-craton lithospheric mantle. Mineralogical Magazine 58A, 703-704.

Pearson, D. G., Shirey, S. B., Carlson, R. W., Boyd, F. R., Pokhilenko, N. P. and Shimizu, N. (1995) Re-Os, $\mathrm{Sm}-\mathrm{Nd}$, and $\mathrm{Rb}-\mathrm{Sr}$ isotope evidence for thick Archaean lithospheric mantle beneath the Silurian craton modified by multistage metasomatism. Geochim. Cosmochim. Acta 59, 959-977.

Qi, Q., Taylor, L. A. and Zhou, X.-M. (1995) Petrology and geochemistry of mantle peridotite xenoliths from SE China. J. Petrol. 36, 55-79.

Qiao, G.-S. (1987) Correction of isotope fractionation in isotopic solution analyses-a new procedure of isotope normalization. Science in China (A) 6, 666672 (in Chinese).

Sen, G., Frey, F. A., Shimizu, N. and Leeman, W. P. (1993) Evolution of the lithosphere beneath Oahu, Hawaii: rare earth element abundances in mantle xenoliths. Earth Planet. Sci. Lett. 119, 53-69.

Steiger, R. H. and Jäger, E. (1977) Subcommission on geochronology; convention on the use of decay constants in geochronology and cosmochronology. Earth Planet. Sci. Lett. 36, 359-362.

Sun, M., Jain, J., Zhou, M.-F. and Kerrich, R. (1993) A procedural modification for enhanced recovery of precious metals (Au, PGE) following nickel sulfide fire assay and tellurium co-precipitation: applications for analysis of geological samples by Inductively Coupled Plasma Mass Spectrometry. Canadian Journal of Applied Spectrometry 38, 103-108.

Sun, S.-S. and McDonough, W. F. (1989) Chemical and isotopic systematics of oceanic basalts: implications for mantle composition and processes. Magmatism in the Ocean Basins (Saunders, A. D. and Norry, M. J., eds.), 313-345, Geological Society Special Publication.

Wang, W. Y., Takahashi, E. and Sueao, S. (1998) Geochemical properties of lithospheric mantle beneath the Sino-Korea Craton; evidence from garnet xenocrysts and diamond inclusions. Phys. Earth Planet. Inter. 107, 249-260.

Xu, S.-T., Okay, A. J., Ji, S., Sengor, A. M. C., Su, W., Liu, Y. and Jiang, L. (1992) Diamond from Dabie Shan metamorphic rocks and its implication for tectonic setting. Science 256, 80-82.

Xu, Y.-G., Menzies, M. A., Bodinier, J.-L., Bedini, R. M., Vroon, P. and Mercier, J.-C. C. (1998) Melt percolation and reaction atop a plume: evidence from the poikiloblastic peridotite xenoliths. Contrib. Mineral. Petrol. 132, 65-84.

Ye, D.-L., Wang, Q., Yang, J.-X. and Ren, Y.-X. (1991) Kimberlites and lamproites in the south Dahongshan, Hubei Province, China. Geological Science and Technology Information 10, Supplement, 37-44 (in Chinese with English abstract).

Zangana, N. A., Downes, H., Thirlwall, M. F. and Hegner, E. (1997) Relationship between deformation, equilibration temperatures, REE and radiogenic isotopes in mantle xenoliths (Ray Pic, Massif Central, France): an example of plume-lithosphere interaction? Contrib. Mineral. Petrol. 127, 187-203.

Zhang, A. D., Xu, D. H., Xie, X. L., Guo, L. H., Zhou, J. X. and Wang, W. Y. (1994) The status and future of diamond exploration in China. Proc. Int. Kimb. Conf. (vol. 2) 5th, 264-269.

Zhang, H.-F. (1998) Petrology and geochemistry of onand off-craton mantle rocks: eastern China and southern Africa. Dr. Sci. Thesis, Royal Holloway University of London, 183 pp.

Zhang, H.-F., Menzies, M. A., Lu, F.-X. and Zhou, X.H. (2000a) Major and trace element studies on garnets from Paleozoic kimberlite-borne mantle xenoliths and megacrysts from the North China Craton. Science in China 43(4), 423-430.

Zhang, H.-F., Menzies, M. A., Zhou, X.-H. and Lu, F.X. (2000b) Textural and chemical zoning in garnets related to mantle metasomatism and deformation processes. Chinese Science Bulletin 45(2), 174-180.

Zheng, J.-P. and Lu, F.-X. (1999) Petrological characteristics in kimberlite-borne mantle xenoliths from 
Shandong and Liaoning Peninsula: Paleozoic lithosphere mantle and its heterogeneity. Acta Petrologica Sinica 15(1), 65-74 (in Chinese with English abstract).

Zhou, J. X., Griffin, W. L., Jaques, A. L., Ryan, C. G. and Win, T. T. (1994) Geochemistry of diamond indicator minerals from China. Proc. Int. Kimb. Conf. (vol. 2) 5th, 285-301.
Zhou, M.-F. (1994) PGE distribution in 2.7 Ga layered komatiite flows from the Belingwe greenstone belt, Zimbabwe. Chem. Geol. 118, 155-172.

Zhou, M.-F., Yumul, G. P., Malpas, J. and Sun, M. (2000) A comparative study of platinum-group elements in the Coto and Acoje Blocks of the Zambales Ophiolite Complex, Philippines. The Island Arc 9, 557-565. 